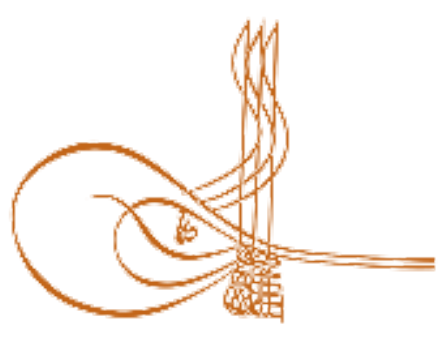

www.turkishstudies.net/education
Turkish Studies - Educational Sciences

eISSN: 2667-5609

Research Article / Araștırma Makalesi

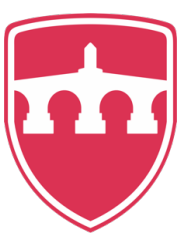

INTERNATIONAL BALKAN

UNIVERSITY Sponsored by IBU

\title{
İlkokul ve Ortaokulda Görev Yapan Öğretmenlerin Örgütsel İkiyüzlülük Algıları ile Örgütsel Bağlılık Davranışları Arasındaki İlişkinin İncelenmesi ${ }^{1}$
}

\author{
Examining of the Relationship Between Organizational Hypocrisy Perception and \\ Organizational Commitment Behaviour of Teachers Working in Primary and Secondary Schools
}

\author{
İlknur Karagül Kandemir ${ }^{*}$ - Gökhan Kahveci**
}

\begin{abstract}
The primary purpose of this research was to identify the relationship between the perceived organizational hypocrisy and organizational commitment of the teachers who worked in the state primary and secondary schools in the city center of Rize province. The population of the study, which was designed as relational screening model, consisted of the teachers who worked in the city center of Rize province. The sample of the research was determined through random sampling among the teachers working in primary and secondary schools. The data of the research were collected in the 2018-2019 academic year. Accordingly, the study was carried out with the participation of 536 teachers. Personal Information Form, Organizational Hypocrisy Scale and Teachers' Organization Commitment Scale were used as data collection tools. In the analysis of the data, descriptive statistics, frequency, mean, and standard deviation were calculated. In order to determine whether the organizational hypocrisy perceptions and organizational commitment behaviors of the teachers varied in terms of demographic variables, t-test and one-way ANOVA parametric tests were performed in conditions where the homogeneity of the group was ensured. When the homogeneity was not provided, in order to identify the group which caused the differentiation, non-parametric tests of Mann Whitney, U-Test, and Kruskal Wallis H-Test were employed. Pearson correlation analysis was performed in order to analyze the correlation between organizational hypocrisy perceptions and organizational commitment behaviors. As a result of the research, the teachers were found to have low organizational hypocrisy perceptions and moderate organizational commitment. It was also revealed that there was a negative and moderate relationship between the teachers' organizational hypocrisy perceptions and
\end{abstract}

\footnotetext{
${ }^{1}$ Bu çalışma birinci yazarın 2019 yılında kabul edilen "İlkokul ve Ortaokulda Görev Yapan Öğretmenlerin Örgütsel İkiyüzlülük Algıları ile Örgütsel Bağlılık Davranışları Arasındaki İlişkinin İncelenmesi” başlıklı yüksek lisans tezinden üretilmiştir. Çalışmanın verileri 2018-2019 eğitim-öğretim yılında toplanmıştır. Bununla birlikte çalışmanın değerlendirilmek üzere Turkish Studies dergisine gönderilmesi yine 2019 y1lı içerisinde gerçekleşmiştir.

* Öğretmen, Milli Eğitim Bakanlığı

Teacher, Ministry of Education

ORCID 0000-0002-4977-1266

ilknur.ozelegtm@gmail.com

** Dr. Öğr. Üyesi- Recep Tayyip Erdoğan Üniversitesi, Eğitim Fakültesi, Eğitim Bilimleri

Assist. Prof. Dr., Recep Tayyip Erdoğan University, Faculty of Education, Educational Sciences

ORCID 0000-0001-6753-3395

gokhan.kahveci@erdogan.edu.tr
}

Cite as/ Atıf: Karagül Kandemir, İ. \& Kahveci, G. (2020). İlkokul ve ortaokulda görev yapan öğretmenlerin örgütsel ikiyüzlülük algıları ile örgütsel bağlılık davranışları arasındaki ilişkinin incelenmesi, Turkish Studies - Education, 15(2), 963-981. https://dx.doi.org/10.29228/TurkishStudies.38898

Received/Geliş: 08 October/Ekim 2019

Accepted/Kabul: 20 April/Nisan 2020

Checked by plagiarism software

Copyright (C) INTAC LTD, Turkey 
organizational commitment behaviors. In addition, it was concluded that the teachers' organizational hypocrisy perceptions were a significant predictor of their organizational commitment behaviors.

Structured Abstract: Introduction Schools are institutions which are affected by their environments while affecting their environment. However, in the adjustment process of schools to their environment, some contrasts and inconsistencies may occur between real practices and their targets and management styles, which is referred to as organizational hypocrisy (Brunsson, 1989). Organizational hypocrisy can lower the success rate of employees, their commitment and job satisfaction (Brunson, 1989; Cha and Edmondson, 2006). It can be argued that organizational hypocrisy decreases organizational trust and organizational justice in educational institutions while increasing organizational cynicism (Kılıçoğlu, Y1lmaz, Kılıçoğlu and Karadağ, 2017) at the same time. However, the limited number of empirical and theoretical studies on what elements of educational institutions organizational hypocrisy will have an effect on makes it difficult to do a detailed research on the concept of organizational hypocrisy (Kılıçoğlu, 2017). Organizational hypocrisy can trigger significant organizational changes. It can even lead to organizational reforms in institutions (Hirschmann, 2012). Paving the way for serious negative impacts, organizational hypocrisy can be seen as a process which generates insincere and dishonest behaviors in the organization (Kılıçoğlu, 2017). One of the most important elements that ensures the employees' productivity is their commitment to their organizations. As the employees' commitment increases, they can sustain their organizational membership voluntarily and fulfill their roles efficiently (Yazıcıoğlu and Topaloğlu, 2009). In institutions where organizational hypocrisy increases, the employees' organizational trust and commitment will decrease. Organizational commitment influences the employees' behaviors (Ponnu and Chuah, 2010). When this situation is considered, the significance of the concept increases twofold. Another significant issue is that the impression created by commitment conflicts with the real behaviors of hypocrisy (Rossi, 2018). Therefore, the perceived hypocrisy is expected to be low while organizational commitment is desired to be high in organizations. This is because institutions need committed employees in order to survive. When national and international literature is examined, it is seen that research on organizational hypocrisy is limited. Consequently, this study is expected to contribute to the literature. To this end, answers to the following questions were sought: What is the level of organizational hypocrisy and organizational commitment perceptions of the teachers who work in primary and secondary schools? Do the organizational hypocrisy and organizational commitment perceptions of the teachers who work in primary and secondary schools differ in terms of the variables of gender, marital status, branch, year of professional service? Is there a significant relationship between the organizational hypocrisy perceptions and organizational commitments of the teachers who work in primary and secondary schools? According to the perceptions of the teachers, does organizational hypocrisy predict organizational commitment?

\section{Method}

Relational screening model was used in the research. The population of the research consisted of teachers in state primary and secondary schools in the city center of Rize province. As it was too difficult to reach the whole population, randomized (simple random) sampling method was employed. Within the scope the research, 536 teachers working in the primary and secondary schools in the city center of Rize were contacted. As the data collection tool, in order to assess the teachers perceived organizational hypocrisy in line with the aim of the research, "Organizational Hypocrisy Scale" developed by Kılıçoğlu, YılmazKılıı̧oğlu and Karadağ (2017) was used. Confirmatory factor analysis was used to determine the construct validity of the scale, and Cronbach Alpha internal consistency coefficient was calculated for determining the reliability of the scale. As a result of the tests performed, Organizational Hypocrisy Scale was found to be valid and reliable. Another scale that was employed was Teacher's Organizational Commitment Scale. This scale was developed by Üstüner in 2009.

\section{Conclusion}

In the perceptions of the teachers regarding organizational hypocrisy, for the year of professional service variable, no statistically significant difference was found in the total score of the scale, keeping promises, the harmony between internal structure and environment dimensions; however, a significant difference was detected in the dimension of inconsistencies in the practices. When this difference was examined, it was seen that in the dimension of inconsistencies in the practices, the perceptions of teachers 
with 11-20 years of service were higher than those of the teachers with 1-10 years and 21 years and above service. The teachers' perception of organizational hypocrisy did not show a significant difference with the demographic variables of gender, branch, marital status, and age.

The teachers' perceptions of organizational commitment were determined to be at a moderate level. It can be stated that many factors play a role in affecting the teachers' commitment to their schools. One of these effective factors is the appointment of individuals with no management skills to the management of schools. The lack of leadership skills in these managers can be said to decrease teachers' organizational commitment. Moreover, managers' unfair treatment of employees can reduce teachers' organizational commitment. According to the results of the study, teachers' perception of organizational commitment displayed a significant difference in terms of gender variable. Similar results were encountered during literature review (Güldiken, 2018; Nacar and Demirtaş, 2017; Şanlı and Arabacı, 2016; Kılıçoğlu, 2010; Sezer, 2005). Accordingly, male teachers' perceptions of organizational commitment were found to be higher than those of female teachers. In line with the results of the study, it can be argued that the lower level of commitment of female teachers compared to male teachers can be explained by some factors such as the social roles they assume, personality traits, responsibilities in the family life and environmental pressure. In addition, the difficulty of the job, student failures, job satisfaction and disinterested students can account for the low organizational commitment of female teachers (Kaya, Polat and Kaya, 2014). Another result of the study was that there was not a significant difference in the teachers' perceptions of organizational commitment for the variables of branch, marital status and year of service.

No difference was found in terms of age variable, but it can be stated that the organizational commitment perceptions of the teachers in the 51 and above years of age group were higher than those of the teachers in other age groups. In line with the purpose of the research, the relationship between the teachers' perceptions of organizational commitment and organizational hypocrisy were examined. To this end, a correlational analysis was carried out in order to identify the relationship between organizational commitment and organizational hypocrisy, as a result of which a negative and moderate relationship was found between the perceptions of organizational commitment and organizational hypocrisy. According to this result, it can be stated that as teachers' perceptions of organizational hypocrisy increase, their organizational commitment is reduced, and that as their level of organizational commitment increases, their perceptions of organizational hypocrisy decrease. Furthermore, in his study, K1lıçoğlu (2017) reached the conclusion that an increase in the perceptions of organizational hypocrisy would result in a decrease in organizational trust and organizational justice and would lead to an increase in organizational cynicism. Accordingly, a decrease in organizational commitment behaviors would occur since organizational trust and organizational justice are among the factors affecting organizational commitment. The study carried out by Candan (2014) supports this result. Furthermore, organizational hypocrisy is considered among the factors causing cynical behavior (Karacaoğlu and Ince, 2012). In the research carried out, it is seen that organizational behaviors affect each other. Therefore, it is important to pay attention to hypocrisy perceptions in order to create a positive climate in the organizations and to ensure organizational trust, organizational justice and organizational commitment. Not only school managers but also all school employees should refrain from behaviors that might create a perception of organizational hypocrisy. Efforts should be made in organizations to decrease organizational hypocrisy and increase organizational commitment. Another result obtained in the study is that organizational hypocrisy significantly predicts organizational commitment. On the other hand, organizational hypocrisy accounts for $40 \%$ of the total variance related to organizational commitment. In line with this result, organizational hypocrisy can be said to be a significant predictor of organizational commitment. Consequently, it can be claimed that there will be an increase in teachers' behaviors regarding organizational commitment in the case where their perceptions of organizational hypocrisy decrease in educational institutions. Organizational hypocrisy decreases employees' work achievement, organizational commitment and job satisfaction (Brunsson, 1989; Cha and Edmondson, 2006) and such studies support the findings of the study. In order to reduce the perceptions of organizational hypocrisy, school managers should show consistent and fair behavior and keep their promises. In addition, teachers should also act in line with their school's targets and conduct educational activities in compliance with the curricula. Thus, organizational hypocrisy perceptions will decrease while organizational commitment behaviors will increase. 


\section{Recommendations}

In-service training can be offered to school employees at schools on what organizational hypocrisy behaviors are and how to take precautions against them. In order to enhance teachers' commitment to schools, a school climate can be created through planning activities such as field trips and dinners. Fair treatment of teachers by school managers will decrease teachers' perceptions of organizational hypocrisy and increase organizational commitment as well. Also, a unit which will supervise school managers and provide guidance to the managers regarding this issue can be established at schools. This research can be replicated by using a mixed method. A research can be carried out on what causes organizational hypocrisy in organizations. In future research, different variables that may affect organizational hypocrisy and their relationships can be examined.

Keywords: Educational Sciences, Organizational Hypocrisy, Organizational Commitment, Primary School, Secondary School.

Öz: Yapılan araştırmanın temel hedefi, Rize il merkezindeki resmi ilkokul ve ortaokullarda görev yapan öğretmenlerin örgütsel ikiyüzlülük algıları ile örgütsel bağllık davranışları arasındaki ilişkiyi ortaya çıkarmaktır. İlişkisel tarama modelinde tasarlanan bu araştırmanın evrenini Rize il merkezinde bulunan resmi ilkokul ve ortaokullarda çalışmakta olan öğretmenler oluşturmaktadır. Araştırmanın örneklemi ise ilkokul ve ortaokullarda görev yapan öğretmenlerden tesadüfi örnekleme yoluyla seçilmiştir. Araştırmanın verileri 2018-2019 eğitim-öğretim yılında toplanmıştır. Bu doğrultuda araştırma 536 öğretmenin katılımıyla gerçekleştirilmiştir. Araştırmada veri toplama aracı olarak Kişisel Bilgi Formu, Örgütsel İkiyüzlülük Ölçeği ve Öğretmenler İçin Örgütsel Bağlılık Ölçeği kullanılmıştır. Verilerin analizinde betimsel istatistik, frekans testi ile ortalama ve standart sapma değerleri alınmıştır. Öğretmenlerin örgütsel ikiyüzlülük algıları ve örgütsel bağlılık davranışlarının demografik değişkenler açısından farklılaşıp farklılaşmadığını belirlemek için homojenliğin sağlandığı koşullarda parametrik testlerden olan t-testi, tek yönlü varyans analizi (one-way ANOVA) testi yapılmıştır. Homojenliğin olmadığı durumlarda farklılığa neden olan grubun belirlenmesinde ise parametrik olmayan testlerden Mann Whitney U-Testi, Kruskal Wallis H- Testi kullanılmıştır. Örgütsel ikiyüzlülük algıları ile örgütsel bağlılık davranışları ilişkisinin analizinde Pearson korelasyon analizi yapılmıştır. Araştırma sonucunda, öğretmenlerin örgütsel ikiyüzlülük algılarının düşük; örgütsel bağlılık algılarının ise orta düzeyde olduğu saptanmıştır. Öğretmenlerin örgütsel ikiyüzlülük algıları ile örgütsel bağlılık davranışları arasında negatif yönlü orta düzeyde anlamlı bir ilişkinin olduğu ortaya ç̧kmıştır. Ayrıca örgütsel ikiyüzlülük algılarının öğretmenlerin örgütsel bağlılık davranışlarının anlamlı bir yordayıcısı olduğu sonucuna ulaşılmıştır.

Anahtar Kelimeler: Eğitim Bilimleri, Örgütsel İkiyüzlülük, Örgütsel Bağlllık, İlkokul, Ortaokul

\section{Giriş}

Belirli hedefleri gerçekleştirmek adına bir araya gelen kişilerden oluşmakta olan örgütler, hedeflerine ulaşabilmek için çağın gereği olan gelişim ve hızlı değişimlere uyum sağlamak durumundadır. Bu gelişim ve değişime uyum sağlaması gereken örgütlerden bir tanesi de eğitim örgütleri olan okullardır. Okullar çevresinden etkilenen ve çevresini etkilemekte olan kurumlar olduğundan devamlılıklarını sağlayabilmek adına çevresindeki değişimlere kayıtsız kalmamalıdır. Ancak okulların çevreye uyum sağlama sürecinde gerçek uygulamalarıyla hedeflerinin ve yönetim biçimlerinin uyumları arasında zitlıklar ya da tutarsızlıklar oluşabilmekte ve bu durum örgütsel ikiyüzlülük olarak tanımlanan örgütsel davranışı oluşturmaktadır (Brunsson, 1989).

Örgütsel ikiyüzlülük, sözler (örgüt içinde az ya da çok resmi olmayan sözbirliği veya tartışmalar), kararlar ve davranışlar arasındaki anlaşmazlıklarda veya kopmalarda ortaya çıkmaktadır (Perez ve Robson, 1999). Örgütsel ikiyüzlülük, çalışanların bağlılığını, işdoyumunu ve iş başarısını azaltabilmektedir (Brunsson, 1989; Cha ve Edmondson, 2006) azaltabilmektedir. Örgütsel ikiyüzlülüğün eğitim kurumları açısından örgütsel güven ve örgütsel adaleti azalttığ1 bunun yanında örgütsel sinizmi (Kılıçoğlu, Yılmaz Kılıçoğlu ve Karadağ, 2017) arttırdığ 
söylenebilir. Ancak örgütsel ikiyüzlülügün eğitim kurumları açısından hangi unsurlara tesir edeceğine ve ne gibi sonuçlar ortaya çıkarabileceğine yönelik ampirik ve teorik araştırmaların sınırlı oluşu örgütsel ikiyüzlülük kavramının ayrıntılı şekilde incelenmesini güçleştirmektedir (Kılıçoğlu, 2017). Örgütsel ikiyüzlülük önemli örgütsel değişiklikleri tetikleyebilir. Hatta örgütsel ikiyüzlülük, kurumlarda örgütsel reformlara da yol açabilmektedir (Hirschmann, 2012). Örgütlerde uzun vadede ciddi olumsuz etkilere yol açabilen örgütsel ikiyüzlülük, örgüt içinde samimi ve dürüst olmayan davranışları üreten bir süreç olarak görülebilir (Kılıçoğlu, 2017). Çalışanların iş başarımına, işe devamlılığına, güvenine, bağl1lı̆̆ına, iş tatmini ve kurumun adalet duygusuna yönelik bir düşüşe neden olabilir (Brunsson, 1989; Cha ve Edmondson, 2006; Philippe ve Koehler, 2005).

Eğitim kurumlarında ise ikiyüzlülük, kişinin okullardaki eylemlerini etkileyen bireylerin tutarsız değerlerini, ilgi alanlarını ve fikirlerini kapsamaktadır (Kılıçoğlu, 2017). Dolayısıyla örgütsel ikiyüzlülük eğitim kurumlarında sadece öğretmenlerden kaynaklanan bir durum değildir. Yöneticiler de örgütsel ikiyüzlülük davranışları sergileyebilirler. Liderliğe ve örgütsel bağl1lığa yaklaşımlar üzerine literatür, liderlerin çalışanların örgütsel bağlllıklarını artırmada büyük rol oynadığını göstermektedir (Buluç, 2009). Dolayısıyla yöneticilerin sergileyecekleri örgütsel ikiyüzlülük davranışlarının öğretmenlerin örgütsel bağlllıklarına olumsuz etki edeceği düşünülmektedir.

Çalışanların verimliliğinin sağlanması noktasında en önemli unsurlardan biri çalışanların örgütlerine bağlılıklarıdır. Bağlılık kelime anlamı olarak sadakat duyma olarak açıklanabilir. Fakat körü körüne bir bağlanma söz konusu değildir. Örgütsel bağl1lık, genel manada bireyin çalıştığ kuruma karşı duyguları anlamına gelir. Çalışanların kurumsal hedeflerini gönülden benimsemeleri, bu amaç neticesinde fazla çalışmaları ve örgütte kalmak istemeleri bağl1lık göstergesidir (Başyiğit, 2006). Örgütsel bağl11ıkta gönüllülük esas olup, aksi durum söz konusu olduğunda bağl11ıktan bahsedilememektedir. Bireyler, bağl1lık düzeyleri arttıkça kurumdaki görev ve sorumluluklarını daha iyi yerine getirebilir ve bu durumu gönüllü olarak devam ettirebilirler (Yazıcıŏlu ve Topaloğlu, 2009). Örgüt yöneticileri için çalışanların bağlılı̆̆ı önemli bir konu olmakla birlikte, bu durum örgütler için her daim sorun oluşturabilmektedir (Brewer, 1996). Bu nedenle örgütsel bağlılık konusunda çokça araştırma yapılmış ancak araştırıcıların ilgisi azalmamıştır. Bağlılık, çalışanı doğrudan etkilediğinden gerek çalışan açısından gerekse yöneticiler açısından önemli bir konu olma özelliğine sahiptir. Yapılan literatür taramasında örgütlerde, örgütsel sessizlik, mobbing, örgütsel sinizm oluşmasında birçok faktör etkilidir. Bu faktörler arasında yerine getirilmeyen sözler, örgütsel ikiyüzlülük, yönetim tarafından önemsenmeme düşüncesi, saygılı bir yaklaşım görememe, gerçek manada yönetim desteği eksikliği kavramları yer almaktadır (Kalay vd., 2014).

Örgütsel ikiyüzlülüğün arttığı kurumlarda, çalışanların örgütsel güveni ve örgütsel bağl1lığ azalacaktır. Örgütsel bağl1lık çalışanların davranışlarını etkilemektedir (Ponnu ve Chuah, 2010). Bu durum göz önünde bulundurulduğunda kavramın önemi bir kat daha artmaktadır. Bir diğer önemli nokta ise bağlılı̆̆ın yarattığı izlenimin, ikiyüzlülüğün gerçek davranışlarıyla çelişiyor olmasıdır (Rossi, 2018). Bu nedenle örgütlerde ikiyüzlülük algılarının düşük, örgütsel bağlılık düzeylerinin yüksek olması beklenmektedir. Çünkü kurumların devamlılığını sağlamak için örgütlerine bağlı çalışanlara ihtiyacı vardır. Dolayısıyla işine bağlı çalışanların çoğunlukta olduğu örgütler yaratmak için var olan örgütsel ikiyüzlülük algısının azaltılması gerekmektedir. Alanyazın incelendiğinde örgütsel ikiyüzlülük ile ilgili sınırlı sayıda çalışmanın olduğu (Kılıçoğlu, 2017; Kılıçoğlu, Yılmaz Kılıçoğlu ve Karadağ, 2019; Konan ve Taşdemir, 2019) görülmektedir. Bu bağlamda yapılan bu çalışma ile hem örgütsel ikiyüzlülük ile ilgili yapılan amprik çalışmaların sayısını arttırılmasının hem de öğretmenlerin okullarına bağlılığının arttırılması noktasında ikiyüzlüğün ne derece etki ettiğinin belirlenmesinin literatüre katkıda bulunacağı düşünülmektedir. Bu araştırmanın hedefi ilkokul ve ortaokulda görev yapan öğretmenlerin algılarına göre örgütsel ikiyüzlülük ile örgütsel bağl1lık arasındaki ilişkinin belirlenmesidir. Bu amaç doğrultusunda şu sorulara cevap aranmıştır. 
1. İlkokul ve ortaokullarda görev yapan öğretmenlerin örgütsel ikiyüzlülük ve örgütsel bağl1lık algıları hangi düzeydedir?

2. İlkokul ve ortaokullarda görev yapan öğretmenlerin örgütsel ikiyüzlülük ve örgütsel bağl1lık algıları; cinsiyet, medeni durum, yaş, branş, mesleki hizmet yılı değişkenleri açısından farklılaşmakta mıdır?

3. İlkokul ve ortaokullarda görevli öğretmenlerin örgütsel ikiyüzlülük algıları ile örgütsel bağl11ıkları arasında anlamlı ilişki var mıdır?

4. Örgütsel ikiyüzlülük, örgütsel bağl1lığı anlamlı şekilde yordamakta mıdır?

\section{Yöntem}

\section{Araştırmanın Modeli}

$\mathrm{Bu}$ araştırma, en az iki değişkenin birlikte değişimlerinin var olması ya da değişim düzeyini ortaya çıkarılmasını amaçlayan ilişkisel tarama modeli esas alınarak tasarlanmıştır (Köse, 2014).

\section{Evren ve Örneklem}

Araştırmanın evrenini, Rize il merkezindeki resmi ilkokul ve ortaokullarda görev yapan 2705 öğretmen oluşturmaktadır. Evrenin tamamına ulaşılmasının güç olduğundan tesadüfi örnekleme metodu kullanılmıştır. Bu metodta, örnekleme birimlerinin her birine eşit olarak seçilme olanağ1 sunularak örneklem alınmaktadır (Büyüköztürk vd., 2016). Bununla birlikte örneklem sayısı belirlenirken uygulanan ölçeklerde bulunan madde sayısının 10 katına ulaşılması göz önünde bulundurulmuştur. Araştırma kapsamında Rize il merkezine bağlı ilkokul ve ortaokulda görevli olan 359 kadın ve 177 erkek olmak üzere toplamda 536 öğretmenle araştırma yapılmıştır.

\section{Veri Toplama Araçları}

\section{Örgütsel İkiyüzlülük Ölçeği (OHS)}

Araştırma yönünde öğretmenlerin örgütsel ikiyüzlülük algılarını ölçmek için Kılıçoğlu, vd. (2017) tarafindan geliştirilen "Örgütsel İkiyüzlülük Ölçeği” kullanılmıştır. Ölçek içerisinde üç alt boyut barındırmaktadır: Sözlerin tutulması, içyapı ve çevre arasındaki uyum ve uygulamalardaki tutarsızlıklar. Ölçek 17 tane 5'li likert tarzında maddelerden oluşmaktadır. Ölçeğin güvenirlik tespiti için Cronbach Alpha iç tutarlılık katsayısı hesaplanmış ve yapı geçerliği için doğrulayıcı faktör analizi yapılmıştır. Yapılan testler neticesinde OHS' nin geçerli ve güvenilir olduğu belirlenmiştir. $\mathrm{Bu}$ araştırma kapsamında geçerlik ve güvenirlik analizleri yeniden yapılmıştır. Ölçeğin yapı geçerliğinin kontrol edilmesi amacıyla Doğrulayıcı Faktör Analizi (DFA) yapılmıştır. Yapılan analizler neticesinde ulaşılan bazı uyum iyiliği değerleri şu şekildedir: $\chi 2 / \mathrm{df}=3.119$ $(\mathrm{p}<.01), \mathrm{CFI}=.944, \mathrm{GFI}=.924, \mathrm{RMSEA}=.063$ ve $\mathrm{SRMR}=.044$. Elde edilen uyum iyiliği değerlerinin iyi uyum gösterdiği belirlenmiştir (Bayram, 2010; Kline, 2011). Bu çalışma kapsamında ölçeğin güverliği için Cronbach Alpha katsayısı hesaplanmıştır. Buna göre Uygulamalardaki tutarsızlıklar boyutunda.81; içyapı ve çevre arasındaki uyum boyutunda.84; sözlerin tutulması boyutunda ise.86, olduğu görülmüş̧ür. Bunun yanında ölçeğin genel güvenirliği.90 olarak bulunmuştur. Böylelikle ölçeğin geçerli ve güvenilir sonuçlar verdiği anlaşılmıştır.

\section{Öğretmenler İçin Örgütsel Bağlılık Ölçeği (ÖİÖBÖ)}

Üstüner tarafından 2009 yılında geliştirilen ölçek, 17 madde ve tek boyuttan oluşmaktadır. Ölçek 5'li likert üzerinden değerlendirilmektedir. Bu araştırma kapsamında ölçek için geçerlik ve güvenirlik analizleri yeniden yapılmıştır. Ölçeğin yapı geçerliğinin kontrol edilmesi amaciyla Doğrulayıcı Faktör Analizi gerçekleştirilmiştir. Elde edilen değerler: $\chi 2 / \mathrm{df}=4,984 \quad(\mathrm{p}<.01)$, $\mathrm{CFI}=, 940, \mathrm{GFI}=, 869, \mathrm{RMSEA}=, 086$ ve $\mathrm{SRMR}=, 0348 . \mathrm{Bu}$ değerlere göre ölçeğin iyi uyum gösterdiği söylenebilir. Ölçeğin Cronbach Alpha katsayısı.96 iken bu araştırma kapsamında 
Cronbach Alpha katsayıs1.97 olarak hesaplanmıştır. Bu sonuçlara göre ölçeğin güvenilir ve geçerli olduğu anlaşılmıştır.

\section{Verilerin Toplanması}

Verilerin toplanması aşamasında öncelikle kullanılan ölçme araçlarını hazırlayanlardan kullanım izni alınmış ve daha sonra gerekli yasal izinler alındıktan sonra ölçme araçları katılımcılara uygulanmaştır. Ölçme araçları yüz yüze veri toplama yöntemi kullanılarak belirlenmiş olan sayı kadar öğretmene gönüllülük esasına dayalı olarak araştırmacı tarafindan uygulanmıştır. Öğretmenlerin ölçekleri doldurmaları 15-20 dakika arasında gerçekleşmiştir.

\section{Verilerin Analizi}

Araştırma bağlamında toplanan verilerin analiz edilmesinde SPSS ve AMOS paket programları kullanılmıştır. Öğretmenlerin örgütsel ikiyüzlülük algıları ve örgütsel bağl1lık davranışlarını belirlemeye yönelik standart sapma frekans testi ve ortalama değerleri alınmıştır. Verilerin dağılımının normallik durumunu test etmek için basıklık (skewness) ve çarpıklık (kurtosis) değerleri incelenmiştir. Gerçekleştirilen analiz sonucunda basıklığın .189 ile.530; çarpıklığın ise .277 ile 1.01 arasında değer aldığı görülmüş ve bu sonuçlara göre normal dağılımın sağlandığı belirlenmiştir (Tabachnick ve Fidell, 2013). Bu aşamadan sonra öğretmenlerin algılarının demografik değişkenler açısından farklılığını belirlemeye yönelik parametrik testlerden t-testi ve tek yönlü varyans analizi; parametrik olmayan testlerden ise Mann Whitney U-Testi, Kruskal Wallis H- Testi kullanılmıştır. Örgütsel ikiyüzlülük algıları ile örgütsel bağlılık davranışları ilişkisinin analizinde Pearson korelasyon analizi yapılmıştır. Korelasyon katsayısı için kabul edilen değer aralığı 0.30-0.00 aralığında ise düşük; 0.70-0.30 aralığında orta; 0.70-1.00 arası yüksek düzeyde bir ilişkinin olduğu şeklinde açıklanmaktadır (Büyüköztürk, 2017). Örgütsel ikiyüzlülüğ̈̈n örgütsel bağlılığı yordama seviyesini belirleyebilmek için ise basit doğrusal regresyon testi yapılmıştır.

\section{Bulgular}

Araştırmanın örneklemini oluşturan öğretmenlerin demografik özellikleri incelendiğinde; cinsiyete göre kadın öğretmenlerin sayısı 359 (\%67), erkek öğretmenlerin sayısı ise 177 (\%33)'dir. Öğretmenlerin branşlara göre dağılımı, branş öğretmenleri 317 (\%59) kişi, sınıf öğretmenlerinin de 219 (\%41) kişidir. Yaş dağılımına bakıldığında; 23 (\% 4.3) kişi 51 ve üzeri yaş aralığında, 84 (\%15.7) kişi 42 -50 yaş aralığında, 20- 30 yaş aralı̆̆ında 174 (\%32.5) kişi, 31-40 yaş aralığında 255 (\%47.6) kişidir. Hizmet yılı dağılımına göre; 284 (\%53) kişinin 1 ile 10 yıl arasında hizmet süresine sahip olduğu, 184 (\% 34.3) kişinin 11-20 hizmet y1lı aralığında olduğu, 68 (\%12.7) kişi ise 21-üzeri hizmet yılına sahiptir. Medeni durum değişkenine göre 161 (\%30) öğretmenin medeni halinin bekâr, 375 (\%70) kişinin ise medeni hali evlidir.

\section{Öğretmenlerin Örgütsel İkiyüzlülük Algılarına Yönelik Bulgular}

Öğretmenlerin örgütsel ikiyüzlülük ölçeğinin toplamına ve boyutlarına yönelik algıları Tablo 1'de gösterilmiştir.

Tablo 1: Örgütsel İkiyüzlülük Algıları

\begin{tabular}{lccc}
\hline Örgütsel İkiyüzlülük & $\mathrm{N}$ & $\bar{X}$ & $\mathrm{SS}$ \\
\hline Sözlerin Tutulması & 536 & 2.18 & 0.70 \\
İç Yapı ve Çevre Arasındaki Uyum & 536 & 2.09 & 0.60 \\
Uygulamalardaki Tutarsılıklar & 536 & 2.34 & 0.78 \\
Toplam & 536 & 2.20 & 0.58 \\
\hline
\end{tabular}

Tablo 1'e göre ikiyüzlülük algıları ortalamaları Sözlerin Tutulması boyutu için $\bar{X}=2.18$; İç Yapı ve Çevre Arasındaki Uyum boyutu için $\bar{X}=2.09$; Uygulamalardaki Tutarsızlıklar boyutu için $\bar{X}=2.34$ ve toplam için $\bar{X}=2.20$ biçimindedir. Ayrıca en düşük ortalama İç Yapı ve Çevre 
Arasındaki Uyum boyutunda, en yüksek ortalama ise Uygulamalardaki Tutarsızlıklar boyutunda olduğu görülmektedir. Öğretmenlerin örgütsel ikiyüzlülük boyutlarına yönelik algılarında maddelere katılma düzeyleri Tablo 2'de sunulmuştur. Cinsiyet değişkeni açısından öğretmenlerin örgütsel ikiyüzlülük algı ortalamalarında farklılık olup olmadığının belirlemesine yönelik t-Testi ve Mann Whitney U Testi gerçekleştirilmiş ve ulaşılan sonuçlar Tablo 2 ve Tablo 3 ’te gösterilmiştir.

Tablo 2: Cinsiyet Değişkeni İçin t-Testi Sonuçları

\begin{tabular}{|c|c|c|c|c|c|c|c|c|c|}
\hline Örgütsel İkiyüzlülük & Cinsiyet & $\mathrm{n}$ & $\bar{X}$ & SS & $\mathrm{F}$ & $\mathrm{p}$ & $\mathrm{t}$ & SD & $\mathrm{p}$ \\
\hline \multirow{2}{*}{ Sözlerin Tutulması } & Kadın & 359 & 2.22 & .69 & \multirow{2}{*}{.45} & \multirow{2}{*}{.50} & \multirow{2}{*}{1.62} & \multirow{2}{*}{534} & \multirow{2}{*}{.11} \\
\hline & Erkek & 177 & 2.11 & .73 & & & & & \\
\hline \multirow{2}{*}{ Uygulamalardaki Tutarsızlıklar } & Kadın & 359 & 2.34 & .79 & \multirow[b]{2}{*}{.13} & \multirow{2}{*}{.72} & \multirow{2}{*}{-.20} & \multirow{2}{*}{534} & \multirow{2}{*}{.84} \\
\hline & Erkek & 177 & 2.35 & .78 & & & & & \\
\hline \multirow{2}{*}{ Toplam } & Kadın & 359 & 2.21 & .57 & \multirow{2}{*}{.34} & \multirow{2}{*}{.56} & \multirow{2}{*}{.11} & \multirow{2}{*}{534} & \multirow{2}{*}{.91} \\
\hline & Erkek & 177 & 2.15 & .59 & & & & & \\
\hline
\end{tabular}

$* \mathrm{p}<.01$

Tablo 2 incelendiğinde Örgütsel İkiyüzlülük, Sözlerin Tutulması ve Uygulamalardaki Tutarsızlıklar boyutlarında dağılımın homojen olduğu görülmektedir. $\mathrm{Bu}$ doğrultuda gerçekleştirilen t-Testi sonucunda; ölçeğin toplamı $\left[t_{(534)}=.11 ; p>.05\right]$, Sözlerin tutulmas $\left[t_{(534)}=\right.$ 1.62; $p>.05]$ ve Uygulamalardaki Tutarsizlıklar $\left[t_{(534)}=-.20 ; p>.05\right]$ boyutlarında cinsiyet değişkeni açısından anlamlı farklılığın olmadığı belirlenmiştir.

Tablo 3: Cinsiyet Değişkeni İçin Mann Whitney U Testi Sonuçları

\begin{tabular}{llllllll}
\hline Boyut & Cinsiyet & $\mathrm{n}$ & $\begin{array}{l}\text { Sira } \\
\text { Ort. }\end{array}$ & Sira Top. & U & Z & $\mathrm{p}$ \\
\hline İç Yapı ve Çevre Arasındaki & Kadın & 359 & 265.27 & 95233.25 & 30613.50 & -.69 & .49 \\
\cline { 3 - 4 } & Erkek & 177 & 275.04 & 48682.50 & Levene \\
& & & & & Testi & F=7.587 & p=.006 \\
\hline
\end{tabular}

Tablo 3 incelendiğinde İç Yapı ve Çevre Arasındaki Uyum boyutunda dağılımın homojen olmadığı görülmektedir. Bu doğrultuda gerçekleştirilen Mann Whitney U testine göre; İç Yapı ve Çevre Arasındaki Uyum $[Z=-.69 ; p>.05]$ boyutu için cinsiyet anlamlı bir farklılık yaratmamıştır.

Öğretmenlerin örgütsel ikiyüzlülük algı ortalamalarının branş değişkeni açısından farklılık olup olmadığını belirlemeye yönelik t-Testi ve Mann Whitney U Testi yapılmıştır. Ulaşılan sonuçlar Tablo 4 ve Tablo 5'te gösterilmiştir.

Tablo 4: Branş Değiş̧keni İçin t-Testi Sonuçları

\begin{tabular}{|c|c|c|c|c|c|c|c|c|c|}
\hline Örgütsel İkiyüzlülük & Branş & $\mathrm{n}$ & $\bar{X}$ & SS & $\mathrm{F}$ & $\mathrm{p}$ & $\mathrm{t}$ & SD & $\mathrm{p}$ \\
\hline Uygulamalardaki Tutarsızlıklar & $\begin{array}{l}\text { Sinıf } \\
\text { Branş }\end{array}$ & $\begin{array}{l}219 \\
317\end{array}$ & $\begin{array}{l}2.27 \\
2.39\end{array}$ & $\begin{array}{l}.82 \\
.75\end{array}$ & 1.10 & .29 & $\begin{array}{l}- \\
1.64\end{array}$ & 534 & .10 \\
\hline Toplam & $\begin{array}{l}\text { Sinıf } \\
\text { Branș }\end{array}$ & $\begin{array}{l}219 \\
317\end{array}$ & $\begin{array}{l}2.20 \\
2.21\end{array}$ & $\begin{array}{l}.62 \\
.55\end{array}$ & 3.99 & .04 & -.30 & 534 & .76 \\
\hline
\end{tabular}

Tablo 4 incelendiğinde Örgütsel İkiyüzlülüğün Toplamı ve Uygulamalardaki Tutarsızlıklar boyutlarında dağılımın homojen olduğu görülmektedir. Bu doğrultuda gerçekleştirilen t-Testi’ne göre; ölçek toplamı $\left[t_{(534)}=-.30 ; p>.05\right]$ ve Uygulamalardaki Tutarsızliklar $\left[t_{(534)}=-1.64 ; p>.05\right]$ boyutunda branş değişkeni açısından anlamlı farklılığın olmadığı belirlenmiştir. 
İlkokul ve Ortaokulda Görev Yapan Öğretmenlerin Örgütsel İkiyüzlülük Algıları ile Örgütsel...971

Tablo 5: Branş İçin Whitney U Testi Sonuçları

\begin{tabular}{|c|c|c|c|c|c|c|c|}
\hline Boyut & Branş & $\mathrm{n}$ & $\begin{array}{l}\text { Sira } \\
\text { Ort. }\end{array}$ & Sira Top. & $\mathrm{U}$ & $\mathrm{Z}$ & $\mathrm{p}$ \\
\hline İç Yapı ve Çevre Arasındaki Uyum & $\begin{array}{l}\text { Sınıf } \\
\text { Branş }\end{array}$ & $\begin{array}{l}219 \\
317 \\
\end{array}$ & $\begin{array}{l}276.11 \\
263.25 \\
\end{array}$ & $\begin{array}{l}60467.00 \\
83449.00 \\
\end{array}$ & 33046.00 & -.95 & .34 \\
\hline \multirow[t]{2}{*}{ Sözlerin Tutulması } & $\begin{array}{l}\text { Sınıf } \\
\text { Branş }\end{array}$ & $\begin{array}{l}219 \\
317 \\
\end{array}$ & $\begin{array}{l}263.98 \\
271.62 \\
\end{array}$ & $\begin{array}{l}57812.00 \\
86104.00 \\
\end{array}$ & 33722.00 & -.56 & .57 \\
\hline & & & & & Levene Testi & $\mathrm{F}=7.587$ & $\mathrm{p}=.006$ \\
\hline
\end{tabular}

Tablo 5 incelendiğinde İç Yapı ve Çevre Arasındaki Uyum ve Sözlerin Tutulması boyutlarında dağılımın homojen olmadığ 1 görülmektedir. Bu doğrultuda gerçekleştirilen Mann Whitney U testi sonucuna göre İç Yapı ve Çevre Arasındaki Uyum $[Z=-.95 ; p>.05]$ ve Sözlerin Tutulması $[Z=-.56 ; p>.05]$ boyutları için branş değişkeni açısından anlamlı bir farklılık olmadığı görülmüştür. Öğretmenlerin örgütsel ikiyüzlülük alg1 ortalamalarının yaş değişkeni açısından farklılık olup olmadığını belirlemeye yönelik tek yönlü varyans analizi gerçekleştirilmiş ve sonuçlar Tablo 6'da gösterilmiştir.

Tablo 6: Yaş Değişkeni İçin Tek Yönlü Varyans Analizi Sonuçları

\begin{tabular}{|c|c|c|c|c|c|c|c|c|c|c|c|c|}
\hline \multirow[t]{2}{*}{ Öİ } & \multirow[t]{2}{*}{ Yaş } & \multirow[t]{2}{*}{$\mathrm{N}$} & \multirow{2}{*}{$\bar{X}$} & \multirow[t]{2}{*}{ SS } & \multicolumn{2}{|c|}{$\begin{array}{l}\text { Homojenlik } \\
\text { Testi }\end{array}$} & \multirow{2}{*}{$\begin{array}{l}\text { Varyansın } \\
\text { Kaynağ } 1\end{array}$} & \multirow{2}{*}{$\begin{array}{l}\text { Kareler } \\
\text { Toplam1 }\end{array}$} & \multirow[t]{2}{*}{ SD } & \multirow{2}{*}{$\begin{array}{l}\text { Kareler } \\
\text { Ortalamas1 }\end{array}$} & \multirow[t]{2}{*}{$\mathrm{F}$} & \multirow{2}{*}{$\mathrm{p}$} \\
\hline & & & & & Levene & $\mathrm{p}$ & & & & & & \\
\hline \multirow{4}{*}{ ST } & $20-30$ & 174 & 2.13 & .70 & \multirow{4}{*}{.51} & \multirow{4}{*}{.68} & \multirow{4}{*}{$\begin{array}{l}\text { Gruplar } \\
\text { Arası } \\
\text { Grup İçi } \\
\text { Toplam }\end{array}$} & .74 & 3 & .25 & .49 & .69 \\
\hline & $31-40$ & 255 & 2.20 & .72 & & & & 266.96 & 532 & .50 & & \\
\hline & $41-50$ & 84 & 2.22 & .68 & & & & 267.70 & 535 & & & \\
\hline & 51üzeri & 23 & 2.11 & .65 & & & & & & & & \\
\hline \multirow{4}{*}{ UT } & $20-30$ & 174 & 2.35 & .82 & & & \multirow{4}{*}{$\begin{array}{l}\text { Gruplar } \\
\text { Aras1 } \\
\text { Grup İçi } \\
\text { Toplam }\end{array}$} & .21 & 3 & .07 & .11 & .95 \\
\hline & $31-40$ & 255 & 2.32 & .75 & .54 & .65 & & 328.82 & 532 & .62 & & \\
\hline & $41-50$ & 84 & 2.35 & .77 & & & & 329.03 & 535 & .07 & & \\
\hline & 51üzeri & 23 & 2.40 & .77 & & & & & & & & \\
\hline \multirow{4}{*}{$\mathrm{T}$} & $20-30$ & 174 & 2.17 & .56 & & & \multirow{4}{*}{$\begin{array}{l}\text { Gruplar } \\
\text { Arası } \\
\text { Grup İçi } \\
\text { Toplam }\end{array}$} & .261 & 3 & .087 & .26 & .86 \\
\hline & $31-40$ & 255 & 2.21 & .60 & 2.03 & .11 & & 179.088 & 532 & .337 & & \\
\hline & $41-50$ & 84 & 2.23 & .56 & & & & 179.349 & 535 & & & \\
\hline & 51üzeri & 23 & 2.21 & .43 & & & & & & & & \\
\hline
\end{tabular}

Not: ÖI: Örgütsel İkiyüzlülük, ST: Sözlerin Tutulması, UT: Uygulamalardaki Tutarsızlıklar, T: Toplam

Tablo 6 incelendiğinde Sözlerin Tutulması, Uygulamalardaki Tutarsızlıklar boyutlarında ve Örgütsel İkiyüzlülük Ölçeğinin toplamında dağılımın homojen olduğu görülmektedir. Bu doğrultuda gerçekleştirilen analiz sonuçlarına göre; Sözlerin Tutulması $\left[F_{(532)}=.49 ; p>\right.$.05], Uygulamalardaki Tutarsızlıklar $\left[F_{(532)}=.11 ; p>.05\right]$ boyutlarında ve ölçeğin toplamında $\left[F_{(532)}=.26\right.$; $p>$.05] yaş değişkeni için farklılık göstermediği tespit edilmiştir. Yaş değişkeni için öğretmen algılarını belirlemeye yönelik Kruskal Wallis H Testi yapılmış ve sonuçlar Tablo 7'de verilmiştir.

Tablo 7: Yaş Değişkeni Açısından Kruskal Wallis H Testi Sonuçları

\begin{tabular}{|c|c|c|c|c|c|c|c|c|}
\hline \multirow{2}{*}{ Boyut } & \multirow{2}{*}{ Yaş } & \multirow{2}{*}{$\mathrm{N}$} & \multirow{2}{*}{ Sira Ortalaması } & \multicolumn{2}{|c|}{ Homojenlik Testi } & \multirow{2}{*}{$\mathrm{X}^{2}$} & \multirow{2}{*}{ SD } & \multirow[b]{2}{*}{$\mathrm{p}$} \\
\hline & & & & Levene & $\mathrm{p}$ & & & \\
\hline \multirow{3}{*}{ İYÇAU } & $20-30$ & 174 & 252.90 & \multirow{3}{*}{2.78} & \multirow{3}{*}{.04} & \multirow{3}{*}{3.11} & \multirow{3}{*}{3} & \multirow{3}{*}{.37} \\
\hline & $31-40$ & 255 & 272.56 & & & & & \\
\hline & $\begin{array}{l}41-50 \\
51 \text { üzeri }\end{array}$ & $\begin{array}{l}84 \\
23\end{array}$ & $\begin{array}{l}285.68 \\
278.78\end{array}$ & & & & & \\
\hline
\end{tabular}

Not: IYYÇAU: İç Yapı ve Çevre Arasındaki Uyum. 
Tablo 7 incelendiğinde İç Yapı ve Çevre Arasındaki Uyum dağılımın homojen olmadığ görülmektedir. Bu doğrultuda gerçekleştirilen test sonuçlarına göre İç Yapı ve Çevre Arasındaki Uyum $\left[X_{(3)}^{2}=3.11 ; p>.05\right]$ boyutu yaş için farkl11ık göstermemektedir. Medeni duruma göre farklıllğın belirlenmesi amaciyla için t-Testi gerçekleştirilmiş ve sonuçlar Tablo 8'de gösterilmiştir.

Tablo 8: Medeni Durum Değişkeni Açısından t-Testi Sonuçları

\begin{tabular}{|c|c|c|c|c|c|c|c|c|c|}
\hline $\begin{array}{l}\text { Örgütsel } \\
\text { İkiyüzlülük }\end{array}$ & $\begin{array}{l}\text { Medeni } \\
\text { Durum }\end{array}$ & $\mathrm{n}$ & $\bar{X}$ & SS & $\mathrm{F}$ & $\mathrm{p}$ & $\mathrm{t}$ & SD & $\mathrm{p}$ \\
\hline Sözlerin Tutulması & $\begin{array}{l}\text { Bekâr } \\
\text { Evli }\end{array}$ & $\begin{array}{l}375 \\
161 \\
\end{array}$ & $\begin{array}{l}2.21 \\
2.11\end{array}$ & $\begin{array}{l}0.72 \\
0.65\end{array}$ & 2.83 & .09 & 1.49 & 534 & .14 \\
\hline $\begin{array}{l}\text { İç Y. ve } \\
\text { Çevre A. U }\end{array}$ & $\begin{array}{l}\text { Bekâr } \\
\text { Evli }\end{array}$ & $\begin{array}{l}375 \\
161 \\
\end{array}$ & $\begin{array}{l}2.10 \\
2.08 \\
\end{array}$ & $\begin{array}{l}0.60 \\
0.57\end{array}$ & .01 & .93 & .42 & 534 & .67 \\
\hline $\begin{array}{l}\text { Uygulamalardaki } \\
\text { Tutarsizlıklar }\end{array}$ & $\begin{array}{l}\text { Bekâr } \\
\text { Evli }\end{array}$ & $\begin{array}{l}375 \\
161 \\
\end{array}$ & $\begin{array}{l}2.35 \\
2.31\end{array}$ & $\begin{array}{l}0.77 \\
0.80 \\
\end{array}$ & .09 & .76 & .58 & 534 & .56 \\
\hline Toplam & $\begin{array}{l}\text { Bekâr } \\
\text { Evli }\end{array}$ & $\begin{array}{l}375 \\
161\end{array}$ & $\begin{array}{l}2.22 \\
2.17\end{array}$ & $\begin{array}{l}0.58 \\
0.56\end{array}$ & .06 & .80 & 1.01 & 534 & .31 \\
\hline
\end{tabular}

Tablo 8'deki sonuçlara göre; ölçeğin toplamı $\left[t_{(534)}=.312 ; p>.05\right]$, Sözlerin Tutulması $\left[t_{(534)}=-.137 ; p>.05\right]$, İç Yap1 ve Çevre Arasındaki Uyum $\left[t_{(534)}=.674 ; p>.05\right]$ ve Uygulamalardaki Tutarsızlıklar $\left[t_{(534)}=.561 ; p>.05\right]$ boyutları için istatistiksel açıdan anlamlı farklılık olmadığ 1 görülmektedir. Hizmet yılı için farklılı̆̆ın belirlenmesi amacıyla tek yönlü varyans analizi yapılmıştır ve bulgular Tablo 9'da gösterilmiştir.

Tablo 9: Mesleki Hizmet Yılı Değişkeni Açısından Tek Yönlü Varyans Analizi Sonuçları

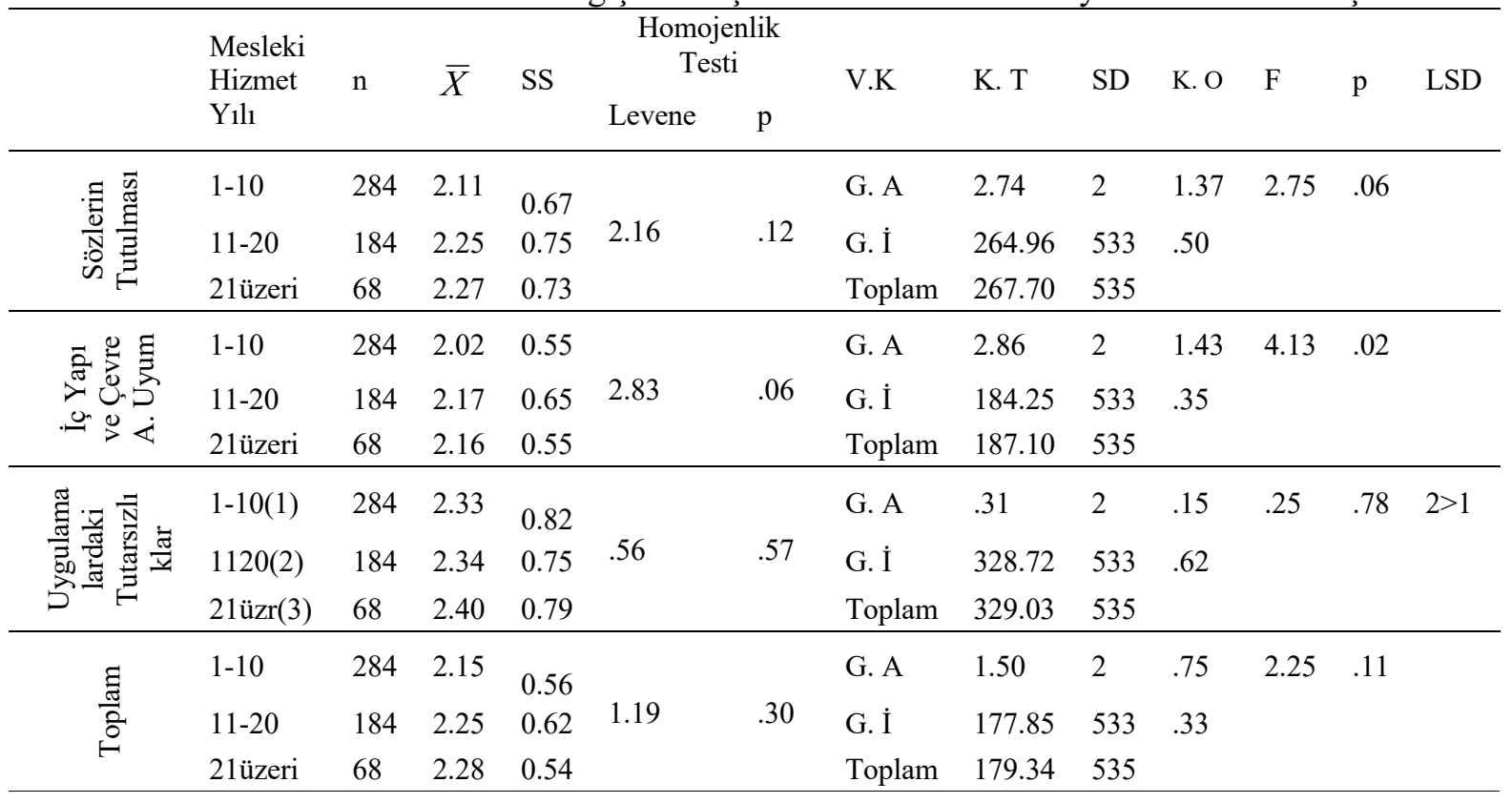

Tablo 9'daki verilere göre ölçeğin toplamı, Sözlerin Tutulması, İç Yapı ve Çevre Arasındaki Uyum ve Uygulamalardaki Tutarsızlıklar boyutlarında dağılımın homojen olduğu görülmektedir. Bulunan sonuçlara göre; mesleki hizmet yılı değişkenine ilişkin ölçeğin toplam1 $\left[F_{(2) .}=2.247 ; p>.05\right]$, Sözlerin Tutulması $\left[F_{(2)}=2.755 ; p>.05\right]$, İç Yap1 ve Çevre Arasındaki Uyum $\left[F_{(2)}=4.134 ; p>.05\right]$ boyutları için istatistikî açıdan anlamlı düzeyde farklılık olmadığı görülmüştür. Uygulamalardaki Tutarsizlıklar $\left[F_{(2)}=.252 ; p>.05\right]$ boyutunda ise anlamlı farkl1l1k olduğu görülmektedir. Bu farklılık incelendiğinde Uygulamalardaki Tutarsılılılar boyutunda 11 ve 20 yıl [ $\bar{X}=2.34]$ hizmet y1lına sahip olan öğretmenlerin algıları, 1-10 [ $\bar{X}=2.33]$ ve 21 - üzeri y1l $[\bar{X}$ 
İlkokul ve Ortaokulda Görev Yapan Öğretmenlerin Örgütsel İkiyüzlülük Algıları ile Örgütsel...973

$=2.40$ ] hizmet yılına sahip olan öğretmenlerin algılarından daha yüksek düzeyde olduğu görülmektedir.

\section{Öğretmenlerin Örgütsel Bağlılık Algılarına Yönelik Bulgular}

Öğretmenlerin ölçeğinin toplamına yönelik algıları Tablo 10'da gösterilmiştir.

Tablo 10: Öğretmenlerin Örgütsel Bağlılık Algıları

\begin{tabular}{lccc}
\hline Örgütsel Bağll1ık & $\mathrm{N}$ & $\bar{X}$ & SS \\
\hline Toplam & 536 & 3.48 & 0.89 \\
\hline
\end{tabular}

Tablo 10'daki verilere bakıldığında öğretmenlerin ölçeğin toplamına yönelik alg1 ortalamasının $\bar{X}=3.48$ olduğu görülmektedir. Katılımcıların cinsiyet değişkenine yönelik örgütsel bağlılık algıları Tablo 11' de sunulmuştur.

Tablo 11: Cinsiyet değișkeni Açısından t-Testi Sonuçları

\begin{tabular}{|c|c|c|c|c|c|c|c|c|c|}
\hline & Cinsiyet & $\mathrm{n}$ & $\bar{X}$ & SS & $\mathrm{F}$ & $\mathrm{p}$ & $\mathrm{T}$ & SD & $\mathrm{p}$ \\
\hline Örgütsel & Kadın & 359 & 3.38 & .91 & 107 & 30 & $403 *$ & 534 & 00 \\
\hline Bağlllık & Erkek & 177 & 3.70 & .82 & 1.07 & .30 & $-4,05$ & 354 & .00 \\
\hline
\end{tabular}

$* \mathrm{p}<.01$

Tablo 11'e bakıldığında örgütsel bağl1lık algılarının cinsiyet değişkenine ilişkin farklılık durumlarını belirlemek için yapılan t-Testi'ne göre; ölçek toplamı $\left[t_{(534)}=-4.03 ; p<.01\right]$ için istatistiksel açıdan anlamlı bir farklılık olduğu görülmüştür. Buna göre kadın öğretmenlerin örgütsel bağl1lık algıları erkek öğretmenlerin örgütsel bağlılık algılarından düşük olduğu görülmektedir. Buna göre erkek öğretmenlerin örgütsel bağlllıkları kadın öğretmenlere göre yüksektir denilebilir. Katılımcıların branş değişkenine ilişkin örgütsel bağlılık algıları Tablo 12'de gösterilmiştir.

Tablo 12: Branş değişkeni Açısından t-Testi Sonuçları

\begin{tabular}{lccccccccc}
\hline & Branş & $\mathrm{n}$ & $\bar{X}$ & $\mathrm{SS}$ & $\mathrm{F}$ & $\mathrm{p}$ & $\mathrm{t}$ & $\mathrm{SD}$ & $\mathrm{p}$ \\
\hline \multirow{2}{*}{ Örgütsel Bağlılık } & Sinıf & 219 & 3.54 & 0.94 & \multirow{2}{*}{3.74} & \multirow{2}{*}{.05} & \multirow{2}{*}{1.30} & \multirow{2}{*}{534} & .19 \\
& Branş & 317 & 3.44 & 0.86 & & & & \\
\hline
\end{tabular}

Tablo 12'ye bakıldığında öğretmenlerin örgütsel bağlılık algılarının branş değişkenine ilişkin farklılık durumunun belirlenmesi doğrultusunda yapılan t-Testi sonucuna göre; ölçek toplamı $\left[t_{(534)}=1.305 ; p>.05\right]$ için istatistiksel anlamda farklılık olmadığı görülmüştür. Buna göre örgütsel bağllık algılarının branş değişkeni açısından benzerlik gösterdiği söylenebilir. Katılımcıların yaş değişkenine ilişkin örgütsel bağlılık algıları Tablo 13 'te gösterilmiştir.

Tablo 13: Yaş Değişkeni Açısından Tek Yönlü Varyans Analizi Sonuçları

\begin{tabular}{|c|c|c|c|c|c|c|c|c|c|c|c|c|}
\hline & \multirow[t]{2}{*}{ Yaş } & \multirow[t]{2}{*}{$\mathrm{n}$} & \multirow[t]{2}{*}{$\bar{X}$} & \multirow[t]{2}{*}{$\mathrm{SS}$} & \multicolumn{2}{|c|}{$\begin{array}{l}\text { Homojenlik } \\
\text { Testi }\end{array}$} & \multirow{2}{*}{$\begin{array}{l}\text { Varyansın } \\
\text { Kaynağı }\end{array}$} & \multirow{2}{*}{$\begin{array}{l}\text { Kareler } \\
\text { Toplamı }\end{array}$} & \multirow[t]{2}{*}{ SD } & \multirow{2}{*}{$\begin{array}{l}\text { Kareler } \\
\text { Ortalamas1 }\end{array}$} & \multirow[t]{2}{*}{$\mathrm{F}$} & \multirow[t]{2}{*}{$\mathrm{p}$} \\
\hline & & & & & Levene & $\mathrm{p}$ & & & & & & \\
\hline \multirow{4}{*}{ 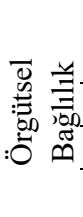 } & $20-30$ & 174 & 3.51 & 0.90 & \multirow{4}{*}{1.08} & \multirow{4}{*}{.36} & $\begin{array}{l}\text { Gruplar } \\
\text { Aras1 }\end{array}$ & 2.34 & 3 & .78 & .98 & .40 \\
\hline & $31-40$ & 255 & 3.43 & 0.89 & & & Grup İçi & 422.72 & 532 & .79 & & \\
\hline & $41-50$ & 84 & 3.52 & 0.84 & & & Toplam & 425.07 & 535 & & & \\
\hline & 51üzr & 23 & 3.72 & 0.87 & & & & & & & & \\
\hline
\end{tabular}

Tablo 13'e bakıldığında öğretmenlerin yaş değişkenine ilişkin örgütsel bağlılık algıları için yapılan tek yönlü varyans analizi'ne göre; ölçek toplamı $\left[F_{(3)}=.984 ; p>.05\right]$ için istatistiki açısından 
anlamlı farklılık bulunmadığı görülmüştür. Katılımcıların medeni durum değişkenine ilişkin örgütsel bağlılık algıları Tablo 14'te gösterilmiştir.

Tablo 14: Medeni Durum değișkeni Açısından t-Testi Sonuçları

\begin{tabular}{llllllllll}
\hline & Medeni Durum & $\mathrm{n}$ & $\bar{X}$ & $\mathrm{SS}$ & $\mathrm{F}$ & $\mathrm{p}$ & $\mathrm{t}$ & $\mathrm{SD}$ & $\mathrm{p}$ \\
\hline \multirow{2}{*}{ Örgütsel Bağl111k } & Evli & 375 & 3.44 & 0.89 & \multirow{2}{*}{.31} & \multirow{2}{*}{.58} & \multirow{2}{*}{-1.69} & \multirow{2}{*}{534} & \multirow{2}{*}{.09} \\
& Bekâr & 161 & 3.58 & 0.87 & & & & & \\
\hline
\end{tabular}

Tablo 14'e göre medeni durum değişkenine ilişkin örgütsel bağllık algıları için yapılan tTesti sonuçları; örgütsel bağl1lı $\left[t_{(534)}=-1.69 ; p>.05\right]$ için anlamlı bir farklılık olmadığını göstermektedir. Örgütsel bağlılık algı ortalamalarının hizmet yılı değişkeni için farklılık gösterme durumunu ortaya çıkarmak için Tek Yönlü Varyans Analizi yapılmış ve Tablo 15'te gösterilmiştir.

Tablo 15: Hizmet Y1lı Değişkenine İlişkin Tek Yönlü Varyans Analizi

\begin{tabular}{|c|c|c|c|c|c|c|c|c|c|c|c|c|}
\hline & \multirow{2}{*}{$\begin{array}{l}\text { Hizmet } \\
\text { Y1li }\end{array}$} & \multirow[t]{2}{*}{$\mathrm{n}$} & \multirow{2}{*}{$\bar{X}$} & \multirow[t]{2}{*}{ SS } & \multicolumn{2}{|c|}{$\begin{array}{l}\text { Homojenlik } \\
\text { Testi }\end{array}$} & \multirow{2}{*}{$\begin{array}{l}\text { Varyansın } \\
\text { Kaynağı }\end{array}$} & \multirow{2}{*}{$\begin{array}{l}\text { Kareler } \\
\text { Toplamı }\end{array}$} & \multirow[t]{2}{*}{ SD } & \multirow{2}{*}{$\begin{array}{l}\text { Kareler } \\
\text { Ortalamas1 }\end{array}$} & \multirow[t]{2}{*}{$\mathrm{F}$} & \multirow{2}{*}{$\mathrm{p}$} \\
\hline & & & & & Levene & $\mathrm{p}$ & & & & & & \\
\hline \multirow{3}{*}{$\begin{array}{l}\text { Örgütsel } \\
\text { Bağlılık }\end{array}$} & $1-10$ & 284 & 3.53 & 0.87 & \multirow{3}{*}{1.17} & \multirow{3}{*}{.31} & G. A & 2.87 & 2 & 1.44 & 1.81 & .16 \\
\hline & $11-20$ & 184 & 3.38 & 0.93 & & & G. İçi & 422.19 & 533 & .79 & & \\
\hline & 21-üst. & 68 & 3.55 & 0.85 & & & Toplam & 425.07 & 535 & & & \\
\hline
\end{tabular}

Tablo 15'e bakıldığında öğretmenlerin hizmet yılı değişkenine ilişkin örgütsel bağlılık algıları sonuçlarına göre; ölçek toplamı $\left[F_{(535)}=1.813 ; p>.05\right]$ için istatistiki açıdan anlamlı farklılık olmadığı görülmüştür.

\section{Örgütsel İkiyüzlülük İle Örgütsel Bağlılık İlişkisine Yönelik Bulgular}

Örgütsel İkiyüzlülük ile Örgütsel Bağlılık arasındaki ilişkileri belirlemek adına yapılan korelasyon analizi sonucunda elde edilen verilen Tablo 16'da gösterilmiştir.

Tablo 16: Örgütsel İkiyüzlülük ile Örgütsel Bağl1lık İlişkisine Ait Korelasyon Analizi Sonuçları

\begin{tabular}{llllll}
\hline & $\begin{array}{l}\text { Sözlerin } \\
\text { Tutulması }\end{array}$ & $\begin{array}{l}\text { Iç Y. Ç. A. } \\
\text { Uyum }\end{array}$ & $\begin{array}{l}\text { Uygulamalardaki } \\
\text { Tutarsızlıklar }\end{array}$ & $\begin{array}{l}\text { Örgütsel } \\
\text { İkiyüzlülük }\end{array}$ & $\begin{array}{l}\text { Örgütsel } \\
\text { Bağl1lık }\end{array}$ \\
\hline Sözlerin Tutulmas1 & 1 & & & & \\
\hline İç Y. Ç. A. Uyum & $.76^{* *}$ & 1 & & & \\
\hline $\begin{array}{l}\text { Uygulamalardaki } \\
\text { Tutarsızlıklar }\end{array}$ & $.47^{* *}$ & $.42^{* *}$ & 1 & & \\
\hline Örgütsel İkiyüzlülük & $.88^{* *}$ & $.84^{* *}$ & $.79^{* *}$ & 1 & \\
\hline Örgütsel Bağl1lık & $-.64^{* *}$ & $-.52^{* *}$ & $-.43^{* *}$ & $-.63^{* *}$ & 1 \\
\hline$* * \mathrm{p}<.01$ & & & & &
\end{tabular}

Tablo 16'da örgütsel bağl1lık ile örgütsel ikiyüzlülük arasında orta düzeyde negatif yönde anlamlı bir ilişki bulunduğu görülmüştür $[r=-.634, p<.01]$. Örgütsel bağlılı̆̆ın geneli ile örgütsel ikiyüzlülügün; sözlerin tutulması $[r=-.640, p<.01]$, içyap1 ve çevre arasındaki uyum $[r=-.522$, $p<.01]$, uygulamalardaki tutarsızlıklar $[r=-.434, p<.01]$, boyutları arasinda orta düzeyde negatif yönde anlamlı bir ilişkinin olduğu görülmektedir. Öğretmenlerin algılarına göre Örgütsel ikiyüzlülüğün örgütsel bağlılığı yordamasına yönelik basit doğrusal regresyon analizi yapılmış ve sonuçlar Tablo 17'de verilmiştir. 
İlkokul ve Ortaokulda Görev Yapan Öğretmenlerin Örgütsel İkiyüzlülük Algıları ile Örgütsel...975

Tablo 17: Örgütsel İkiyüzlülüğün Örgütsel Bağl1lık Üzerindeki Etkisine Yönelik Regresyon Analizi Sonuçları

\begin{tabular}{lcccccc}
\hline \multicolumn{1}{c}{ Değişken } & & $\mathrm{B}$ & Std. Error & $\mathrm{B}$ & $\mathrm{t}$ & $\mathrm{p}$ \\
\hline \multirow{2}{*}{ Örgütsel İkiyüzlülük } & Sabit & 5.63 & .12 & & $47.99^{*}$ & .00 \\
& Örgütsel Bağll1.k & -.98 & .05 & -.63 & $-18.95^{*}$ & .00 \\
\hline & & & $\mathrm{R}=.63$ & $\mathrm{R}^{2}=.40$ & $\mathrm{~F}_{(1.534)}=359.100^{*}$ & $\mathrm{p}=.00$ \\
\hline *p $<.01$ & & & & &
\end{tabular}

Tablo 17'ye bakıldığında örgütsel ikiyüzlülük örgütsel bağlılığı anlamlı olarak yordadığı görülmektedir $\left[R=.63, R^{2}=.40, F_{(1.534)}=359.104, p=.000\right]$. Bunun yanında örgütsel ikiyüzlülük, örgütsel bağlılığa ilişkin toplam varyansın \% 40'ını açıklamaktadır. Ulaşılan bu sonuca göre öğretmenlerin sahip oldukları ikiyüzlülük algılarının, örgüte olan bağlılıklarını önemli derecede etkilediği ifade edilebilir.

\section{Tartışma, Sonuç ve Öneriler}

$\mathrm{Bu}$ araştırmada, öğretmenlerin sahip oldukları ikiyüzlülük algılarının düşük seviyede olduğu sonucuna varılmıştır. Bu sonuca benzer şekilde Kılıçoğlu (2017) öğretmenlerin ikiyüzlülük algılarını düşük düzeyde bulmuştur. Bu sonuçtan farklı olarak Kılıçoğlu vd., (2019) ile Kıllıçoğlu (2015) yaptıkları araştırmalarda öğretmenlerin örgütsel ikiyüzlülük algılarının orta düzeyde olduğunu bulgulamışlardır. Araştırma sonucuna göre Öğretmenlerin örgütsel ikiyüzlülük algılarında mesleki hizmet yılı değişkeni için, ölçeğin toplamı, sözlerin tutulması, içyapı ve çevre arasındaki uyum boyutları, istatistiki açıdan anlamlı bir farklılık görülmezken; uygulamalardaki tutarsızlıklar boyutunda anlamlı farklılık bulunduğu belirlenmiştir. Bu farklılık incelendiğinde uygulamalardaki tutarsızlıklar boyutunda 11 ve 20 hizmet yılına sahip olanların algiları, 1-10 y1l ve 21- üzeri yıl hizmet yılına sahip olan öğretmenlerin algılarından daha yüksek düzeyde olduğu görülmektedir. Öğretmenlerin örgütsel ikiyüzlülük algıları cinsiyet, branş, medeni durum, yaş demografik değişkenleri için anlamlı şekilde farklılılaşmamaktadır.

Araştırmadan elde edilen diğer bir sonuç, öğretmenlerin bağlılık algılarının orta düzeyde olduğudur. Alanyazın incelendiğinde araştırma ile paralellik göstermekte olan çalışmalar bulunmaktadır. Alcan (2018), Mahmutoğlu (2007), Öztürk (2014) ve Tan (2017), tarafindan gerçekleştirilen çalışmalarda da öğretmenlerin orta düzeyde bağl1lık algılarına sahip olduğu görülmüştür. Bunların dışında Girgin ve Demir (2018) yaptıkları araştırmada örgütsel bağlılığın öğretmenler tarafından yüksek düzeyde algılandığını belirtmişlerdir. Yukarıdaki sonuçlar değerlendirildiğinde, öğretmenlerin okullarına dolayısıyla işlerine bağlılıklarının istenilen düzeyde olduğu ifade edilebilir.

Araştırma sonucunda, cinisyet değişkeni için öğretmenlerin bağ l1lık algılarının farklılaştığ tespit edilmiş ve erkek öğretmenlerin kadın öğretmenlere göre bağlllık algılarının daha yüksek olduğu belirlenmiştir. Alanyazına bakıldığında yapılan bu araştırma sonucuna benzer bulgular görülmüştür (Güldiken, 2018; Alcan, 2018; Nacar ve Demirtaş, 2017; Şanlı ve Arabac1, 2016; Kılıçoğlu, 2010; Sezer, 2005;). Bu sonuca göre erkek öğretmenlerin örgütsel bağl1lık algıları kadın öğretmenlerin örgütsel bağl1lık algılarından daha yüksek olduğu görülmüştür. Buna göre erkek öğretmenlerin örgütsel bağlılıkları kadın öğretmenlere göre daha yüksektir denilebilir. Bu sonuca ek olarak Mathieu ve Zajac (1990) ve McClurg (1999), kadınların erkeklere oranla bağlılıklarının daha yüksek düzeyde oldukları sonucuna ulaşmışlardır. Bu sonuçlardan farklı olarak Balay (2000), Erdaş (2009), Öztürk (2014) ve Özkan'ın (2005) gerçekleştirmiş oldukları farklı araştırmalarda öğretmenlerin sahip oldukları bağll1ık algılarının cinsiyet için bir farklılık göstermediği sonucuna ulaşmışlardır. 
Araştırmadan elde edilen sonuçlara göre, kadın öğretmenlerin yüklenmiş oldukları toplumsal rolleri, kişilik özellikleri, aile hayatındaki sorumlulukları, çevre baskıları bağlılıklarının erkek öğretmenlere göre daha düşük bağl1lık göstermelerine neden olduğu söylenebilir. Bu duruma paralel olarak Kaya, Polat ve Kaya (2014) yaptıkları araştırmada kadın öğretmenlerin örgütsel bağlılığının azalmasında işin zorluğu, öğrenci başarısızlıkları, iş tatmini ve öğrencilerin ilgisiz olma gibi faktörlerinde etkili olduğunu ifade etmektedirler.

Araştırma sonucunda, öğretmenlerin bağl1lık algılarında branş değişkeni için anlamlı farklılık görülmemiştir. Bu sonuçların aksine öğretmenlerin örgütsel bağlılık algılarının branş değişkenine göre anlamlı farklılık göstermediği sonucuna varmıştır. Araştırma sonuçlarıyla paralel sonuçlara ulaşan çalışmalar bulunmaktadır (Atik ve Üstüner, 2014; Balçık, 2018; Erdaş, 2009; Nacar ve Demirtaş, 2017; Öztürk, 2014). Bu sonuca göre öğretmenlerin bağlılık algılarında branş değişkenin önemli bir etkiye sahip olmadığı ifade edilebilir.

Araştırma sonucunda, öğretmenlerin bağl1lık algilarında yaş değişkeni için farklılık görülmemiştir. Bu sonuçların aksine Yalçın ve İplik (2005), Gören (2012), yapmış oldukları araştırmalarda yaş değişkeni açısından farkl1lık tespit etmişler ve yaş ilerledikçe örgüte bağl1lığın arttığını bulgulamışlardır. Bu araştırma sonuçlarına paralel olan çalışmalar da alanyazında yer almaktadır (Alcan, 2018; Nacar ve Demirtaş, 2017; Öztürk, 2014; Durna ve Eren, 2005). Araştırma sonucuna göre yaş değişkeni bağlamında bir farklılık görülmemiştir ancak 51 yaş ve üzeri yaş grubunda bulunan öğretmenlerin algılarının, diğer yaş gruplarındaki öğretmenlerin algılarına göre daha yüksektir. Bu durumun öğretmenlerin yaşlarının ilerlemesi sonucu insan doğası gereği daha fazla duygusal olmalarından kaynaklandığı ifade edilebilir.

Araştırmada medeni durum değişkeni için öğretmenlerin bağlılık algılarının farklılaşmadığ belirlenmiştir. Bu sonucun aksine Zeyrek (2008), Özkaya, Deveci Kocakoç ve Kara (2006), Ateş ve Buluç (2018), medeni durum değişkeninin örgütsel bağlılığ etkilediğini belirtmişlerdir. Bu araştırma sonuçlarına paralel sonuçlar elde eden araştırmalar alanyazında mevcuttur (Yalçın ve İplik, 2005; Kömürcüoğlu, 2003). Yukarıdaki bilgiler 1şığında medeni durumun öğretmenlerin bağlılık algılarını önemli derecede etkilemediğ söylenebilir. Bununla birlikte, medeni durumu evli olanların sorumluluk bilinci yüksek olmakta ve bu durum da örgütsel bağl1lı̆g kuvvetlendirmektedir. Buna paralellik gösteren araştırmalar bulunmaktadır. Bu araştırmada öğretmenlerin, mesleklerinin doğası gereği öğrencilerini, sınıflarını, işlerini sevmeleri, medeni durumlarının örgütsel bağl111klarını farklılaştırmama sebebi olarak gösterilebilir.

Araştırma sonucunda, hizmet yılı değişkeninin öğretmenlerin bağlilık algılarını farklılaştırmadığı görülmüştür. Ulaşılan bu sonucu destekleyen araştırmalar bulunmaktadır (K1lıçoğlu, 2010; Nacar ve Demirtaş, 2017; Özsoy, 2004; Uğraşoğlu ve Çağanağa, 2017). Bu bulgunun aksine Alcan (2018) yaptığı araştırmada örgütsel bağlılık algılarını çalışma yılı değişkeninin etkilediği sonucuna ulaşmıştır. Çalışmada 26 ve üstü hizmet yılına sahip öğretmenlerin diğer gruplarda yer alan öğretmenlere göre bağlılık algıları daha yüksek olmakla birlikte, 6-15 hizmet yılı grubunda yer alan öğretmenlerin en düşük bağlılık algısına sahip olduğunu belirtmiştir. Bunun yanında İhtiyaroğlu (2018) ve Atik ve Üstüner (2014) öğretmenlerin örgütsel bağl1lığı ile mesleki hizmet y1lı arasında anlamlı farklılık bulmuşlardır. 26 y1l ve üstü mesleki hizmet yılına sahip çalışanların diğer hizmet yılı gruplarına oranla örgütsel bağlılıklarının daha yüksek olduğu sonucuna varmışlardır.

Araştırmada, öğretmenlerin sahip oldukları ikiyüzlülük algıları ile bağlılık algıları arasında negatif yönde bir ilişkinin olduğu belirlenmiştir. Bu sonuca göre öğretmenlerin örgütsel ikiyüzlülük algıları arttıkça, örgütsel bağl1lık düzeyleri düşer; örgütsel bağl1lık düzeyleri arttıkça da örgütsel ikiyüzlülük algılarının azalabileceği söylenebilir. Bunun yanında, Kılıçoğlu (2017), yaptığ1 çalışmada örgütsel ikiyüzlülük algılarının artmasının örgütsel güveni ve örgütsel adaleti azaltacağı ayrıca örgütsel sinizmi arttırabileceği sonucuna ulaşmıştır. Bu doğrultuda örgütsel bağlılık 
davranışlarında da azalma olacaktır, çünkü örgütsel güven ve örgütsel adalet örgütsel bağl1lığ1 etkileyen faktörler arasındadır. Candan (2014) yapmış olduğu araştırma bu durumu desteklemektedir. Dolayısıyla örgütsel adalet ve örgütsel güven örgütsel bağl1lık algılarına aracılık etmektedir (Yanık ve Naktiyok, 2017). Ayrıca, örgütsel ikiyüzlülük sinizm davranışına neden olan faktörler arasında gösterilmektedir (Karacaoğlu ve İnce, 2012). Araştırmalara bakıldığında örgütsel davranışların birbirini etkilediği görülmektedir. Dolayısıyla örgütlerde olumlu bir iklim oluşturmak, örgütsel güven, örgütsel adalet ve örgütsel bağl1lı̆̆ sağlamak adına örgütsel ikiyüzlülük algılarına dikkat etmek gerekmektedir. Gerek okul yöneticilerinin gerekse okul çalışanlarının tümünün örgütsel ikiyüzlülük algısı yaratacak davranışlardan kaçınması gerekmektedir. Örgütlerde örgütsel ikiyüzlülüğü azaltıcı ve bağlılı̆̆ yapılmalıdır. Aksi durumda örgütte ikiyüzlülük algıları artış göstererek olumsuz davranışlardan oluşan bir örgüt ortamı oluşabilir.

Araştırmada ulaşılan bir diğer sonuç ise, örgütsel ikiyüzlülüğün örgütsel bağl1lığı anlamlı bir şekilde yordamasıdır. Elde edilen bu bulgudan hareketle, eğitim örgütlerinde örgütsel ikiyüzlülük algılarının azalmasının, öğretmenlerin örgütsel bağlılık davranışlarını olumlu yönde etkileyeceği ifade edilebilir. Örgütsel ikiyüzlülük algılarının azaltılması için okul yöneticilerinin tutarlı ve adil davranması, verdiği sözleri yerine getirmesi gerekmektedir. Bunun yanında öğretmenlerin de okulun amaçlarına uygun davranması, hazırlanan öğretim programlarına uyumlu şekilde eğitim-öğretim faaliyetlerini yürütmesi gerekmektedir. Böylelikle örgütsel ikiyüzlülük algıları azalıp örgütsel bağlılık davranışları artar.

\section{Öneriler}

Araştırma sonuçları doğrultusunda araştırmacılara ve uygulayıcılara çeşitli öneriler getirilmiştir. Okullarda hangi davranışların örgütsel ikiyüzlülük davranışı kapsamına girebileceği ve bu davranışlar için ne gibi önlemler geliştirilebilceğine yönelik okul çalışanlarına bu konu hakkında bilgilendirici eğitimler ve seminerler verilebilir. Öğretmenlerin okula bağlılıklarını arttırmak adına okul gezileri, kahvaltı, yemek gibi etkinliklerin planlanabildiği bir okul iklimi oluşturulabilir. Okul yöneticilerinin öğretmenlere adil şekilde davranması örgütsel ikiyüzlülük algılarını azaltacak ve örgütsel bağlılığı da arttırabilecektir. Okul yöneticilerinin çalışmalarını denetleyen ya da yöneticilere rehberlik edebilecek bir okul biriminin kurulması sağlanabilir. Öğretmenlerin örgütsel ikiyüzlülük algıları arttıkça, örgütsel bağlılık algıları azalacaktır. Bu sonuçtan yola çıkarak, öğretmenlerin örgütsel ikiyüzlülük algılarını azaltabilecek olan okul yönetiminin özellikle uygulamalardaki tutarsızlıklar hakkında okul yöneticileriyle bilgilendirme toplantıları düzenlenerek daha bilinçli olmaları sağlanabilir.

Öncelikle gerçekleştirilen bu çalışma, farklı ve daha fazla çeşitliliğe sahip örneklemlerde (lise, anaokulu, üniversiteler vb.) gerçekleştirilebilir. Bunun yanında, bu araştırma ileride hem nitel hem de nicel yöntemler birlikte kullanılara karma yöntem şeklinde tekrarlanabilir. Bu bağlamda alanyazında yeni sayılabilecek ikiyüzlülük kavramı ile ilgili daha derinlemesine bilgiler elde edilebilir. Örgütlerde örgütsel ikiyüzlülüğe nelerin neden olduğu, araştırılabilir. İlerde yapılacak olan çalışmalarda örgütsel ikiyüzlülük algılarını etkileyebilecek olan çeşitli değişkenlerle arasındaki ilişkileri inceleyen araştırmalar yapılabilir. 


\section{Kaynakça}

Alcan, E. E. (2018). Öğretmenlerin örgütsel destek, örgütsel özdeşleşme ve örgütsel bă̆lllık algıları arasındaki ilişki (Yüksek Lisans Tezi). https://tez.yok.gov.tr/UlusalTezMerkezi adresinden edinilmiştir.https://doi.org/10.26466/opus.418335

Atik, S., \& Üstüner, M. (2014). İlköğretim okullarının örgüt tipi ile öğretmenlerin örgütsel bağl1lığ1 arasındaki ilişki. Ahi Evran Üniversitesi Kırşsehir Eğitim Fakültesi Dergisi, 15(2), 133154.https://doi.org/10.17240/aibuefd.2019.19.49440-541193

Balay, R. (2000). Yönetici ve ögretmenlerde örgütsel bă̆lllık. Ankara: Nobel Yayın Dağıtım.

Balçık, E. (2018). Örgüt kültürü, psikolojik güçlendirme ve örgütsel bağlllık arasındaki ilişkiler (Yükssek Lisans Tezi). Pamukkale Üniversitesi açık erişim arşivi adresinden edinilmiştir. https://doi.org/10.19171/uefad.459546

Başyiğit, A. (2006). Örgütsel iletişimin örgütsel bağlllık üzerine etkisi (Yüksek Lisans Tezi). https://tez.yok.gov.tr/UlusalTezMerkezi adresinden edinilmiştir.

Bayram, N. (2010). Yapısal eşitlik modellemesine giriş amos uygulamaları. Ezgi Kitabevi, İstanbul.

Brewer, A. M. (1996). Developing commitment between managers and employees. Journal of Managerial Psychology, 11(4), 24-34.https://doi.org/10.1108/02683949610117599

Brunsson, N. (1989). The organization of hypocrisy: Talk, decisions and actions in organizations. New York: John Wiley and Sons.

Buluç, B. (2009). Sınıf öğretmenlerinin algılarına göre okul müdürlerinin liderlik stilleri ile örgütsel bağl1lık arasındaki ilişki. Kuram ve Uygulamada Eğitim Yönetimi, 15(57), 534.https://doi.org/10.14527/kuey.2014.006

Büyüköztürk, Ş., Çokluk, Ö., \& Köklü, N. ( 2011). Sosyal bilimler için istatistik. Ankara: Pegem Akademi.https://doi.org/10.14527/9789756802335

Candan, H. (2014). Çalışanların örgütsel adalet ve örgütsel güven algılamalarının örgütsel bağl1lığa etkisi: Bir kamu kurumu üzerinde araştırma. Gaziantep University Journal of Social Sciences, 13(4), 889-917.https://doi.org/10.29131/uiibd.358527

Cha, S., \& Edmondson, A. (2006). When values backfire: Leadership, attribution, and disenchantment in a values-driven organization. Leadership Quarterly, 17, 5778.https://doi.org/10.1016/j.leaqua.2005.10.006

Çapık, C. (2014). Geçerlik ve güvenirlik çalışmalarında doğrulayıcı faktör analizinin kullanımı. Anadolu Hemşirelik ve Săgllk Bilimleri Dergisi, 17(3), 196205.https://doi.org/10.26559/mersinsbd.543459

Durna, U., \& Eren, V. (2005). Üç bağl11ık unsuru ekseninde örgütsel bağl111k. Doğuş Üniversitesi Dergisi, 6(2), 210-219.https://doi.org/10.31671/dogus.2019.273

Erdaş, Y. (2009). Denizli il merkezinde çalışan ilköğretim öğretmenlerinin örgütsel bağlllık düzeyleri (Yüksek Lisans Tezi). https://tez.yok.gov.tr/UlusalTezMerkezi adresinden edinilmiştir.

Girgin, S., \& Demir, T. (2018). Meslek lisesi öğretmenlerinin örgütsel bağl1llğa ilişkin algıları. Uluslararası Bilimsel Araştırmalar Dergisi, 3(1), 12-24.https://doi.org/10.21733/ibad.2161

Güldiken, A. (2018). Örgütsel bağlllık ve örgütsel tükenmişlik ilişkisi ile ilgili kamu kurumu çalışanları üzerinde bir araştırma (Yüksek Lisans Tezi). 
İlkokul ve Ortaokulda Görev Yapan Öğretmenlerin Örgütsel İkiyüzlülük Algıları ile Örgütsel...979 https://tez.yok.gov.tr/UlusalTezMerkezi/ https://doi.org/10.18394/iid.532018

adresinden

edinilmiştir.

Gören, T. (2012). Illköğretim kurumlarında görev yapan yönetici ve ögrretmenlerin örgütsel bağlllık düzeyleri (Yüksek Lisans Tezi). https://tez.yok.gov.tr/UlusalTezMerkezi/ adresinden edinilmiştir.

Hirschmann, G. (2012). Peacebuilding in UN peacekeeping exitstrategies: Organized hypocrisy and institutional reform. International Peacekeeping, 19(2), 170-185. https://doi.org/10.1080/13533312.2012.665686

İhtiyaroğlu, N. (2018). Analysis of relationship between teachers' coping styles with stress and the level of organizational commitment. International Online Journal of Educational Sciences, 10(2), 192-206. DOI: https://doi.org/10.15345/iojes.2018.02.013.

Kalay, F., Oğrak, A., \& Nişanc1, Z. N. (2014). Mobbing, örgütsel sessizlik ve örgütsel sinizm ilişkisi: Örnek bir uygulama. Kastamonu University Journal of Economics \& Administrative Sciences Faculty, 4(2), 127-143.https://doi.org/10.26449/sssj.843

Karacaoğlu, K., \& İnce, F. (2012). Brandes, Dharwadkar ve Dean'in (1999) örgütsel sinizm ölçeği Türkçe formunun geçerlilik ve güvenilirlik çalışması: Kayseri organize sanayi bölgesi örneği. İşletme ve Ekonomi Araştırmalart Dergisi, 3(3), 77-92. https://doi.org/10.11611/yead.545638

Kaya, F. Polat, F., \& K, S. (2014). Resmi ilköğretim okullarında görev yapan öğretmenlerin örgütsel bağl1lı̆̆a ilişkin görüşleri: Elazı̆̆ ili örneği. Milli Eğitim, 202, 59-75. https://doi.org/10.17679/iuefd.99916

Kılıçoğlu, G. (2010). İlköğretim Okulu Öğretmenlerinin Örgütsel Bağlllık Algılarının Bazı Değişkenler Açısından Incelenmesi (Yüksek Lisans Tezi). https://tez.yok.gov.tr/UlusalTezMerkezi/ladresinden edinilmiştir. https://doi.org/10.17051/ilkonline.2019.610798

Kılıçoğlu, G. (2017). Örgütsel ikiyüzlülük ve bütünlüğün Türkiye bağlamında incelenmesi: Teorik bir çözümleme. Kuram ve Uygulamada Eğitim Yönetimi, 23(3), 465-504. https://doi.org/10.14527/kuey.2014.005

Kılıçoğlu, G., Yılmaz-Kılıçoğlu, D. ve Karadağ, E. (2019). Do schools fail to "walk their talk”? Development and validation of a scale measuring organizational hypocrisy. Leadership and Policy in Schools, 18(1), 52-82.https://doi.org/10.1080/15700763.2017.1371762

Kline, R., B. (2011). Principles and practice of structural equation modeling, (3th ed.), The Guildfor Press, New York, London.

Konan, N., \& Taşdemir, A. (2019). Öğretmenlerin örgütsel ikiyüzlülük algılları ile örgütsel mutluluk düzeyleri arasındaki ilişki. Bilimsel Eğitim Araştırmaları, 3(2), 132-152. https://doi.org/10.31798/ses.655939

Kömürcüoğlu, H. (2003). Belirsizlik ortamında iş tatmini ve işe bağl1lık. İ̧̧ Güç Endüstri İlişkileri ve Insan Kaynaklarl Dergisi, E-Dergi, $\quad$ 5(1). 12.10.2018, $\mathrm{http} / / / \mathrm{www}$.isguc.org/?p=article\&id=36\&cilt=5\&sayi=1\&yil=2003.

Köse, E. (2014). Bilimsel araştırma yöntemleri. R. Y. Kıncal, (Ed.), Bilimsel araştırma modelleri. (99-122).Ankara: Pegem Akademi.https://doi.org/10.14527/9786052419649.02

Mahmutoğlu, A. (2007). Milli eğitim bakanlığı merkez örgütünde iş doyumu ve örgütsel bağlllık (Doktora Tezi). https://tez.yok.gov.tr/UlusalTezMerkezi/_ adresinden edinilmiştir. 
Mathieu, J. E., \& Zajac, D. M. (1990). A review and meta-analysis of the antecedents, corralates and consequences of organizational commitment. Physcological Bulletin, 108(2), 171-194. https://doi.org/10.1037/0033-2909.108.2.171

McClurg, L. N. (1999). Organizational commitment in the temporary-help service industry. Journal of Applied Management Studies, 8(1), 5-26.

Nacar, D. \& Demirtaş, Z. (2017). Lise öğretmenlerinin örgütsel bağl1lık düzeyleri. Uluslararası Türk Eğitim Bilimleri Dergisi, 547-558. https://doi.org/10.26466/opus.469281

Özkan, Y. (2005). Örgütsel sosyalleşme sürecinin öğretmenlerin örgüte bağlllıklarına etkisi (Yüksek Lisans Tezi). https://tez.yok.gov.tr/UlusalTezMerkezi//adresinden edinilmiştir.

Özkaya, M. O., Kocakoç, İ. D. \& Kara, E. (2006). Yöneticilerin örgütsel bağl1lıkları ve demografik özellikleri arasındaki ilişkileri incelemeye yönelik bir alan çalışması. Celal Bayar Üniversitesi. Yönetim ve Ekonomi Dergisi, 13(2), 77- 96. https://doi.org/10.18657/yecbu.04098

Özsoy, A. S. (2004). Bir yüksekokul çalışanlarının kuruma bağlılık durumlarının incelenmesi. $\dot{I S S ̧ s}_{\text {, }}$ Güç Endüstri İlişkileri ve Insan Kaynakları Dergisi, 6(2), 13-19.

Öztürk, H. (2014). Ortaokullarda görev yapan öğretmenlerin sessizlik ile örgütsel bağlllı algıları arasındaki ilişkinin incelenmesi (Yüksek Lisans Tezi).https://tez.yok.gov.tr/UlusalTezMerkezi/ adresinden edinilmiştir. https://doi.org/10.12780/uusbd.62827

Perez, L. F., \& Robson, K. (1999). Ritual legitimation, de-coupling and the budgetary process: managing organizational hypocrisies in a multinational company. Management Accounting Research, 10, 383-407.https://doi.org/10.1006/mare.1999.0114

Phillippe, T. W., \& Koehler, J. W. (2005). A factor analytical study of perceived organizational hypocrisy. SAM Advanced Management Journal, 70(2), 13-20.

Ponnu, C.H., \& Chuah, C. C. (2010). Organizational commitment, organizational justice and employee turnover in Malaysia. University of Malaya, Kuala Lumpur, Malaysia, 4(13), 2676-2692.

Rossi, B. (2018). The Commitment account of hypocrisy. Ethical Theory and Moral Practic, 21(3), 553-567. doi:10.1007/s10677-018-9917-3.

Sezer, F. (2005). İlköğretim okulu müdürlerinin sergiledikleri liderlik stillerinin öğretmenlerin örgütsel bağlllı̆̆ına etkisi (Yüksek Lisans Tezi). https://tez.yok.gov.tr/UlusalTezMerkezi/ adresinden edinilmiştir.

Şanlı, Ö., \&Arabacı, İ.B. (2016). Liselerde çalışan öğretmenlerin örgütsel kimlik ve örgütsel imaj algılarının örgütsel bağl1lıklarına etkisi. Education Sciences (NWSAES), 11(3), 126-152. https://doi.org/10.12739/nwsa.2016.11.3.1c0658

Tabachnick, B. G., \& Fidell, L. S. (2013). Using multivariate statistics. Boston, Pearson.

Tan, S. (2017). Öğretmen Algılarına Göre Örgütsel Sağlık ve Örgütsel Bă̆lllık Arasındaki İlişkinin Incelenmesi (Yüksek Lisans Tezi). https://tez.yok.gov.tr/UlusalTezMerkezi adresinden edinilmiştir.https://doi.org/10.11611/jmer299

Uğraşoğlu, İ. K., \& Çağanağa, Ç. K. (2017). Öğretmenlerin örgütsel bağl1lık düzeylerinin farklı değişkenler açısından incelenmesi. International Journal of News Trends in Arts Sports \& Science Education, 6(4), 10-38. 
İlkokul ve Ortaokulda Görev Yapan Öğretmenlerin Örgütsel İkiyüzlülük Algıları ile Örgütsel...981

Üstüner, M. (2009). Teachers' organizational commitment scale: A validity and reliability study. Inonu University Journal of The Faculty of Education, 10(1), 1-17.

Yalçın, A., \& İplik F. N. (2005). Beş yıldızlı otellerde çalışanların demografik özellikleri ile örgütsel bağlılıkları arasındaki ilişkiyi belirlemeye yönelik bir araştırma: Adana ili örneği. Çukurova Üniversitesi Sosyal Bilimler Enstitüsü Dergisi, 14(1), 395-412. https://doi.org/10.18037/ausbd.632111

Yanık, O., \& Naktiyok, A. (2017). Etik (ahlaki) liderliğin çalışanların iş tatminine, örgütsel bağlllı̆̆ına ve işten ayrılma niyetine etkisinde örgütsel güven ve örgütsel adalet algısının arac1 rolü. Bartın Üniversitesi I.I. .B.F. Dergisi, 8(15), 297-324. https://doi.org/10.18026/cbayarsos.486680

Zeyrek, A. O. (2008). Milli eğitim bakanlı̆̆ 2005 ögretmenlik kariyer basamakları yükselme sinavında öğretmenlerin başarı durumları ile örgütsel bağlllıkları arasındaki ilişsinin incelenmesi (Yüksek Lisans Tezi). https://tez.yok.gov.tr/UlusalTezMerkezi adresinden edinilmiştir.https://doi.org/10.17755/esosder.263221 